UDC 547.567.5

\author{
B. Murashevych, N. Nychyk, N. Toropin, Y. Trush, K. Burmistrov
}

\title{
CHEMICAL PROPERTIES OF SOME NEW QUINONEIMINE DERIVATIVES
}

\author{
Ukrainian State University of Chemical Technology, Dnipro, Ukraine
}

\begin{abstract}
The reactions between some $\mathrm{C}_{8}$-substituted quinonearenalazines (their chloro- and aminoderivatives) and hydrogen chloride were investigated. It is shown that in the case of chloroderivatives these reactions lead to the formation of the aromatic 1,4- and 6,3-addition products mixture, regardless of the used solvent. The ratio between these isomers depends on the oxidation-reduction potential of initial quinoneimine. An increase in the acceptor properties of the substitute in the aromatic ring of substrate results in an increase in the content of 1,4-addition product. The addition products are quinogenic and can be oxidized to the corresponding quinoid forms. The last mentioned compounds exist only in antiform in the case of 6,3-addition of hydrogen chloride, while oxidized 1,4-addition products are the mixture of syn- and anti-isomers, which convincingly follows from the NMR spectra of these compounds. Amino-derivatives of quinonearenalazines do not react neither with hydrogen chloride nor with amines, perhaps, due to a considerable decrease in electron deficiency of quinoid cycle under the influence of entered aminogroup.
\end{abstract}

Keywords: quinoneimine, quinonearenalazine, addition, regioselectivity, oxidation-reduction potential, hydrogen chloride.

DOI: $10.32434 / 0321-4095-2019-125-4-101-108$

\section{Introduction}

It is known that quinoneimines of different structure, being electron deficient substances, are highly chemical active and readily interact with nucleophilic agents. Reactions of addition to the quinoneiminesare often accompanied by aromatization of the quinoid cycle with introduction of the substitute into the quinogenic oxygen or nitrogen atoms in ortho-position [1,2]. In some cases, the addition products undergo cyclizations to form heterocyclic compounds $[3,4]$. The transimination reactions of quinoneimines with the preservation of quinoid cycle (1,2-addition-elimination) have been also described [5]. Such diversity of the chemical properties causes the wide range of practical useful qualities of quinoneimines derivatives. Nowadays,quinoid compounds are widely used in medicine and pharmacy for the treatment of atherosclerosis, mitochondrial diseases, as the element of complex therapy of head injuries and neurological disfunctions, particularly Alzheimer's and Parkinson's diseases [6-8].

Reaction of the 1,8-addition to quinoneimines, which was discovered by us for the first time, being a new direction in the chemistry of the quinoid compounds, allows preparing the quinoneimines derivatives never described before with satisfactory yields. The purpose of the current study is to investigate the chemical properties of some of them, namely the products of 1,8-addition of the hydrogen chloride and dialkyl- and arylamines to the quinine arenalazines.

Theory

The existing conception about interdependence between regioselectivity of the addition of hydrogen chloride to quinoneimines and their oxidationreduction potentials (ORP) allows successfully predicting the position of the substitute (chlorine atom) in the reaction product. In most cases, it is ortho-position towards the quinogenic oxygen or nitrogen atom. However, the interaction between quinonearenalazines (I) and hydrogen chloride proceeds according to the 1,8-addition scheme, independent of the ORP $[9,10]$. The addition products (II) are quinogenic and can be easily oxidized to the corresponding chlorine derivatives (III) [11-13] (Scheme 1).

The reason for such scheme is the relatively high stability of the possible intermediate structure with aromatized quinoid cycle $\mathrm{C}$ in comparison with 
<smiles>[Li]C(Cl)=NN=C1C=CC(=O)C=C1</smiles>

Scheme 1<smiles>O=C1C=CC(N/N=C/[15Cl])=CC1Cl</smiles>

A<smiles>OC1=CC(Cl)C(=N/N=C/Br)C=C1</smiles>

B<smiles>Oc1ccc(/N=N/C(Cl)(Br)Br)cc1</smiles>

C

Scheme 2

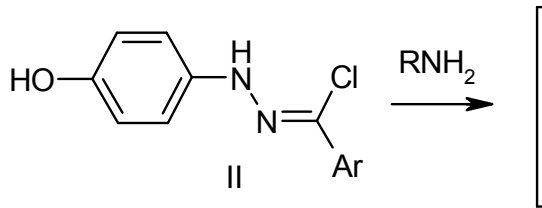

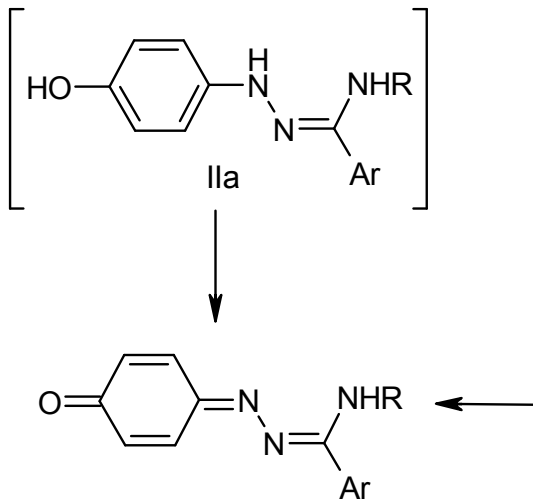

IV<smiles>O=C1C=CC(=N/N=C(/Cl)Br)C=C1</smiles>

III

Scheme 3

classical structures A and B (Scheme 2).

Chlorine atom in the compounds (II) and (III) is mobile and can be replaced by aminogroup, and in the both cases the final reaction products are the amidrazones of 1,4-benzoquinone (IV) (Scheme 3) [11-13].

The products (IIa) cannot be separated in a pure form from the reaction mixture due to their fast oxidation, apparently, by air oxygen. This fact points at the vast decrease of the ORP as a result of the replacement of chlorine by aminogroup.

It is obvious that compounds (III, IV) cannot undergo 1,8-addition, since exocyclic carbon atom of the azomethine group has been already occupied. However, the ortho-positions towards the quinogenic oxygen and nitrogen atoms are free, so it can be assumed that classical 1,4- and 6-3-addition reactions may flow readily. It is supposed that regioselectivity of these reactions depends on the ORP of the quinoneimine [14]: those quinonearenalazines, which have lower ORP than 1,4-benzoquinone, must undergo 6,3-addition reactions with the formation of corresponding aminophenols with substitute in ortho-position towards quinoid nitrogen; for those with the ORP higher than 1,4-benzoquinone, the 1,4 -addition must be more characteristic, and in this case substitute must occurinto the ortho-position towards the oxygen atom (Scheme 4).

The ORP values of the quinonearenalazines, that have been measured before, are lying within the range of $430-495 \mathrm{mV}$, that is less than the ORP of 1,4-benzoquinone $(0.583 \mathrm{mV}$ in $0.5 \mathrm{M}$ solution of sodium acetate in acetic acid). It has been shown previously that electron acceptors, conjugated with quinoid cycle, increase their ORP, and electron donors, in opposite, decrease it [14]. The ORP of the compounds (II-IV) have not been measured yet, but partially the rule described above for this systems confirmed by oxidation ease of substances (IIa). Based on this, we could assume that the reactions between compounds (IV) and different nucleophiles will proceed according to the 1,8addition scheme, and regioselectivity of the addition to compounds (III) can vary depending on substitute in the aromatic ring of the quinoneimine molecule.

\section{Results and discussion}

To achieve the goal of the study, the series of $\mathrm{N}$-[ $\alpha$-chlor-(aryliden) $]-\mathrm{N}^{\prime}-(4$-hidroxyphenyl)- 


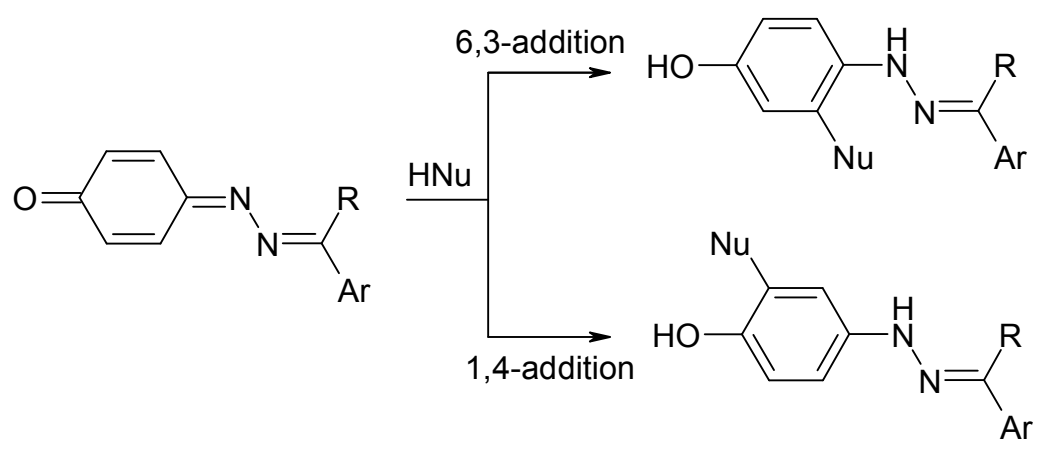

Scheme 4

hydrazines (II a-d) and their oxidized forms, [ $\alpha-$ chlor)-aryliden]hydrazono-2,5-cyclohexadiene-1ones (III a-d), have been synthesized by the method described elsewhere [10]. The choice of the initial compounds is due to their ORP, which values must increase in the following sequence: IIId $<$ IIIc $\leq$ IIIb $<$ $<$ 1,4-benzoquinone $<$ IIIa. Quinoneimines (III a-d) have been introduced into the reaction with hydrogen chloride (Scheme 5).

The reaction was carried out in acetic acid or in 1,2-dichloroethane with the identical qualitative results and insignificant distinctions in the product's yields. In all cases except methoxy-derivative (III d), the reaction mixture contained two colorless new compounds, which with high probability represented the products of 1,4-addition ( $\mathrm{V} \mathrm{a}-\mathrm{d}$ ) and 6,3-addition (V a'-d'), and the impurity of the corresponded arylaldehyde. In the case of p-nitroderivative (IIIa), the ratio of the addition products is $1: 1$ (as was determined by thin-layer chromatography), and it is about 1:4 for the substrates (III b) and (III c). Only one product is observedin the case of quinoneimine (III d), and it oxidizes intensively upon attempts to separate it.

For the determination of the structure of the synthesized products, the reaction mixture of the $\mathrm{N}$-[ $\alpha$-chloro-(4-bromobenzyliden]-N'-(4-hydroxyphenyl)hydrazine (III c) has been scrupulously analyzed. The products ( $\mathrm{Vc})$ and ( $\mathrm{Vc}$ ') has been separated via column chromatography. Their mass ratio after obtaining in the pure crystal form turned out to be 1:4, as it was determined earlier by TLC. NMR ${ }^{1} \mathrm{H}$ spectra of these products are characterized by the same set of signals, which have minimal distinctions in the chemical shifts (Fig. 1).

The signals from the protons of the hydroxyand aminogroups, 1,4-substituted phenyls and 1,2,4substituted benzene ring are observed in the spectra. The signal from the azomethine group is absent. Thus, the spectra prove the assumed structure of these products, but do not allow determining the direction of chlorine atom attachment.

To deal with this problem, compounds $(\mathrm{Vc})$ and ( $\mathrm{Vc}^{\prime}$ ) has been oxidized by lead dioxide into corresponding quinoid forms (VIc) and (VI c') (Scheme 6).<smiles>O=C1C=CC(=NN=C([Al])Cl)C=C1</smiles>

III a-d<smiles>Oc1ccc(NN=C([Al])Cl)c(Cl)c1</smiles>

Va-d $V a^{\prime}-d^{\prime}$

$$
\mathrm{Ar}=\mathrm{p}-\mathrm{O}_{2} \mathrm{~N}^{-} \mathrm{C}_{6} \mathrm{H}_{4^{-}}(\mathrm{a}), \mathrm{p}-\mathrm{Cl}-\mathrm{C}_{6} \mathrm{H}_{4^{-}} \text {(b), p-Br- } \mathrm{C}_{6} \mathrm{H}_{4}-(\mathrm{c}), \mathrm{p}-\mathrm{CH}_{3} \mathrm{O}-\mathrm{C}_{6} \mathrm{H}_{4} \text { (d) }
$$

Scheme 5<smiles>Oc1ccc(N/N=C(\Cl)c2ccc(Br)cc2)cc1Cl</smiles>

Vc

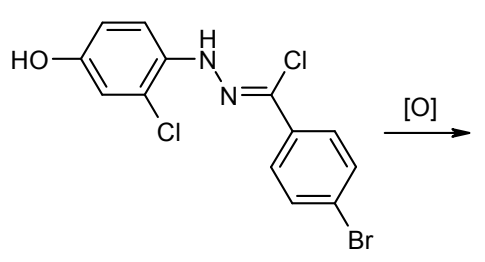

$\mathrm{Vc}^{\prime}$

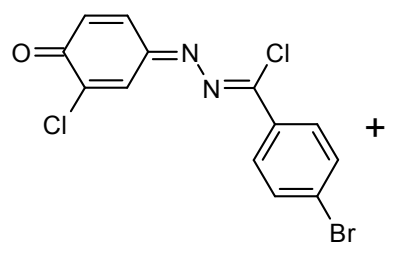

VIc

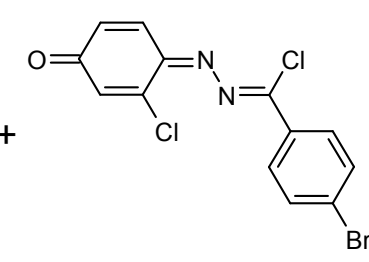

VIc'

Scheme 6 


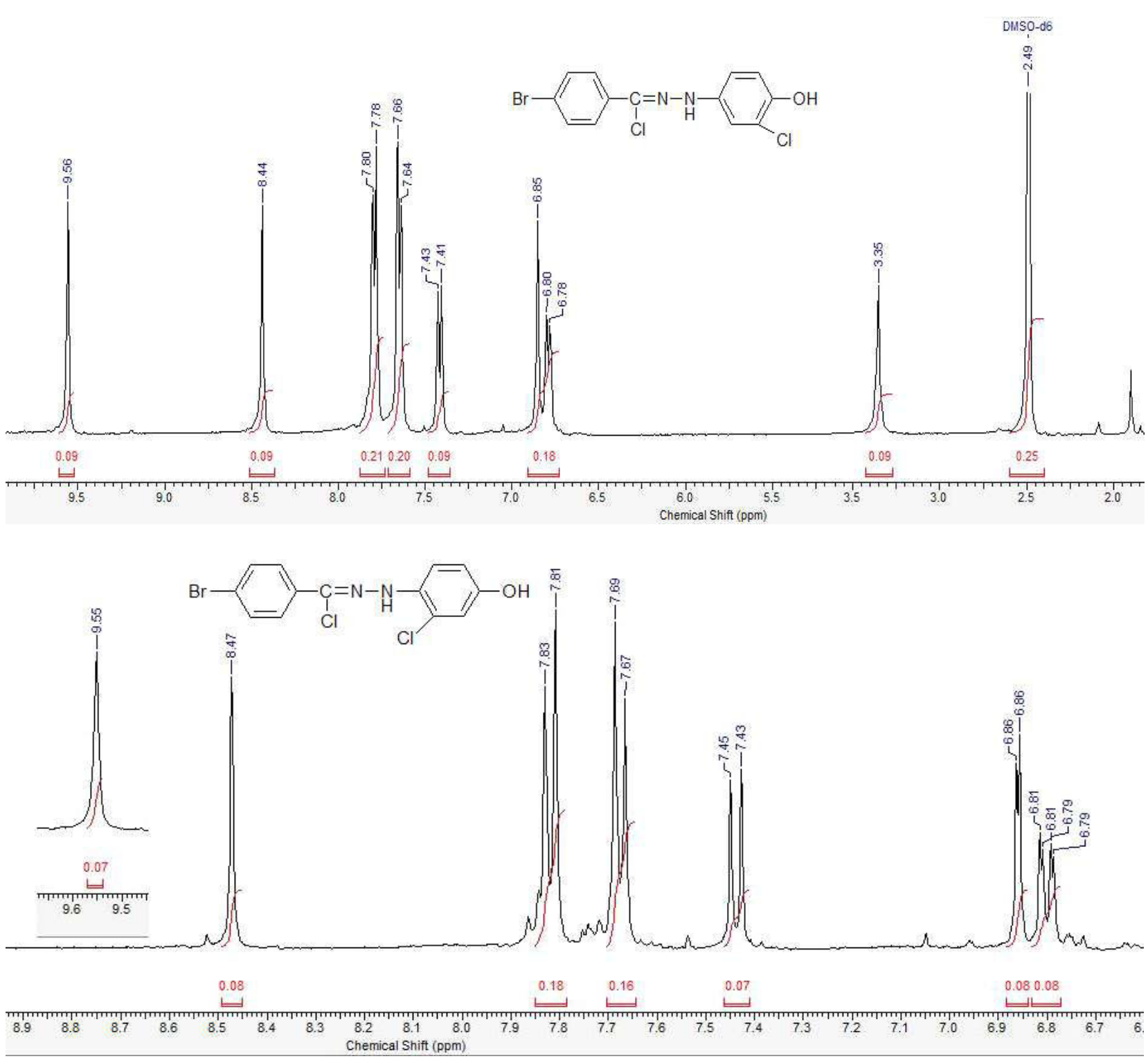

Fig. 1. NMR ${ }^{1} \mathrm{H}$ spectra of the compounds (Vc) and (Vc')

NMR ${ }^{1} \mathrm{H}$ spectra of these compounds are much more informative and allow identifying them precisely (Fig. 2).

The signals of the protons of the hydroxyl- and aminogroups are absent in both spectra, which proves the quinoid structure of the products. The signals of the aromatic protons are almost the same too. However, there are two sets of the quinoid cycle signals in the spectrum of the compound (VIc), in opposite to (VI c'), which is due to the possibility of the isomerization around $=\mathrm{N}-\mathrm{C}=$ bond of the quinoid cycle and, consequently, the existence of two conformers (VIc-syn) and (VIc-anti) (Scheme 7).

The analysis of the integral intensities of these signals indicates that the conformers content ratio syn:anti is $1: 2$. In the spectra of the oxidized product of the 6,3-addition ( $\mathrm{Vc}^{\prime}$ ), such situation is not observed, since the steric difficulties of the syn-isomer<smiles>O=C1C=CC(=NN=C(Cl)c2ccc(Br)cc2)C=C1Cl</smiles>

Scheme 7

this compound exists only in anti-form. An analogous conclusion can be drawn regarding the NMR ${ }^{1} \mathrm{H}$ 

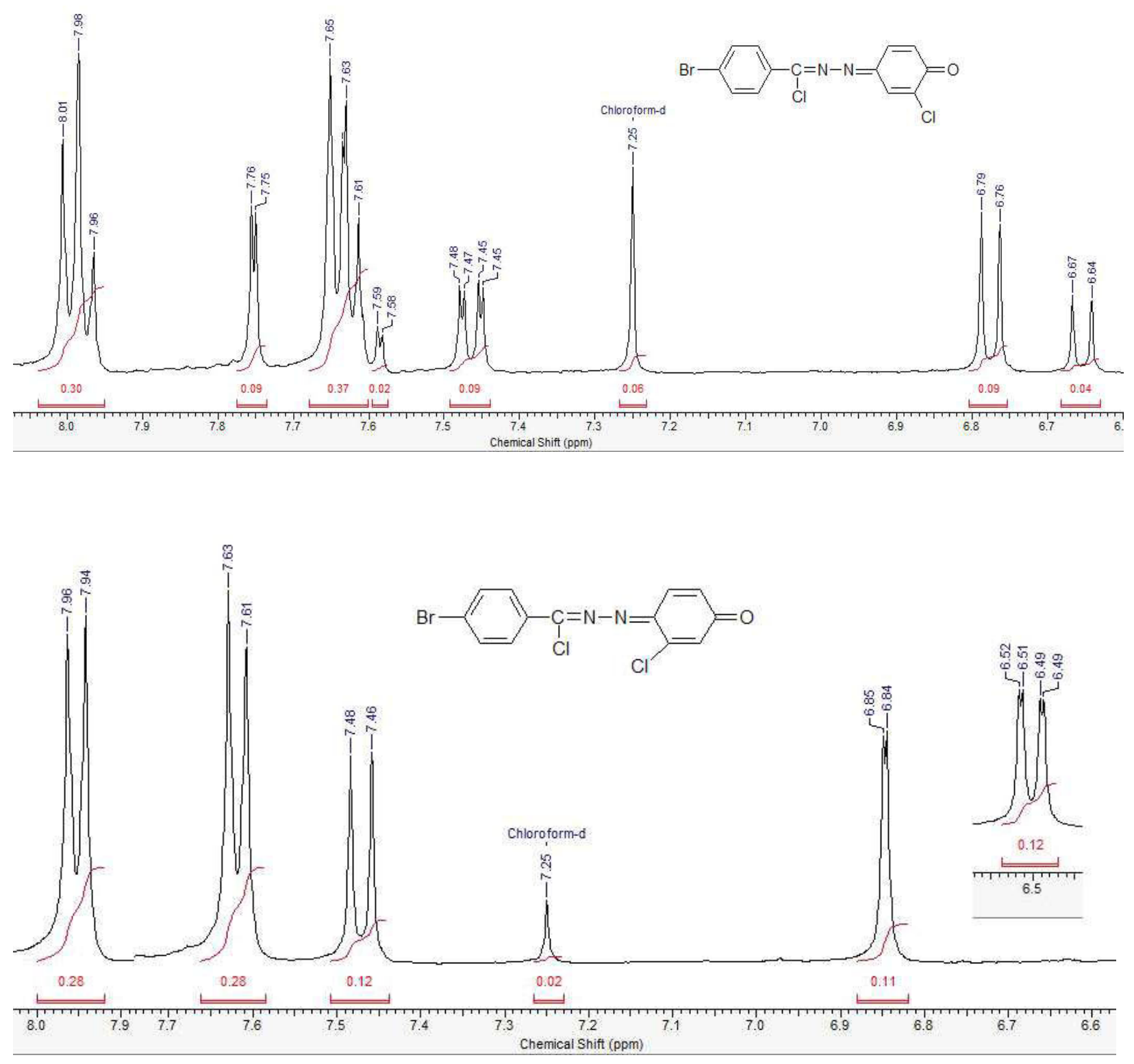

Fig. 2. NMR ${ }^{1} \mathrm{H}$ spectra of the compounds (VIc) and (VIc')

spectra of the product of oxidation of the pmethoxysubstitutedazine (VId) (Scheme 8, Fig. 3).

As can be seen, this compound exists only in the form of the anti-conformer, that proves that arenalazine (IIId) undergoes only 6,3-addition of hydrogen chloride in full accordance with the theory of the ORP of quinoneimines.

The definitive confirmation of the structure of the synthesized substances has been obtained by the independent synthesis of the compound $(\mathrm{Vc})$ from the ortho-chlorophenol by the method described elsewhere [15]. The physicochemical constants and spectral characteristics of the obtained product are

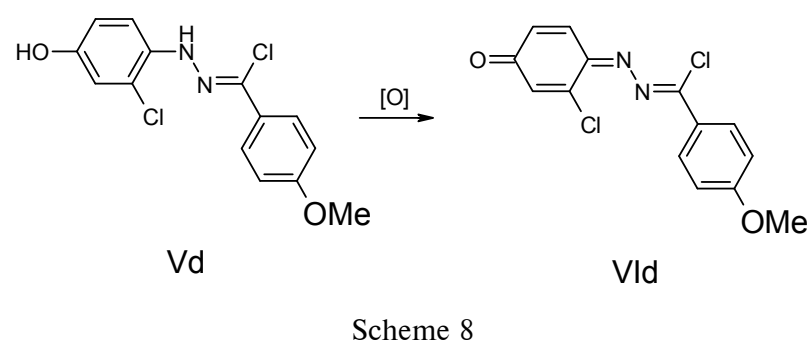

totally identical with those of the product separated from the reaction mixture.

The obtained results allowed determining the ratio between the products of 1,4- and 6,3-addition 


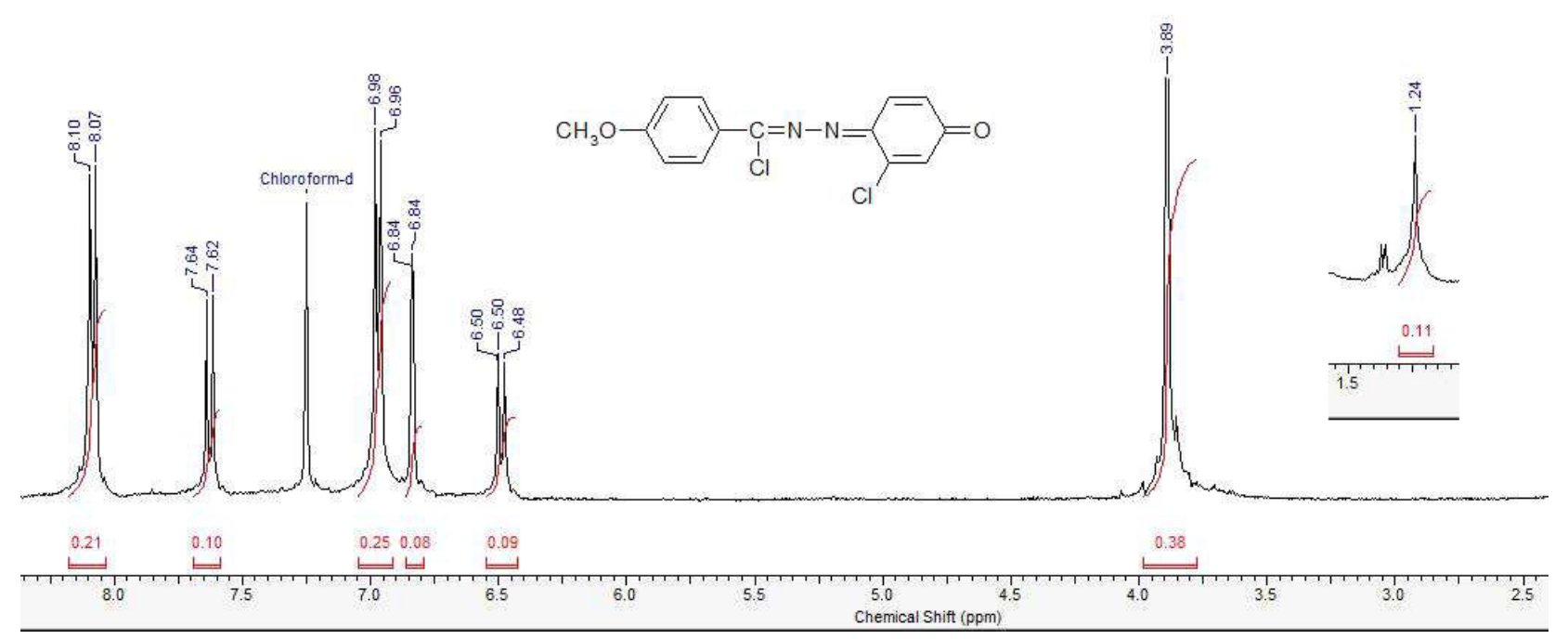

Fig. 3. NMR ${ }^{1} \mathrm{H}$ spectra of the compounds (VId)

of hydrogen chloride to compounds (IIIa) and (IIIb) too. The summarized data are given in Table.

Ratio between 1,4- and 6,3-addition of hydrogen chloride isomers

\begin{tabular}{c|c|c}
\hline Substance & $\begin{array}{c}\text { Percentage of } \\
1,4 \text {-addition product }\end{array}$ & $\begin{array}{c}\text { Percentage of } \\
6,3 \text {-addition product }\end{array}$ \\
\hline IIIa & 50 & 50 \\
\hline IIIb & 20 & 80 \\
\hline IIIc & 20 & 80 \\
\hline IIId & 0 & 100 \\
\hline
\end{tabular}

As is seen, an increase in acceptor properties of the substitute in the aromatic ring of substrate leads to an increase in the percentage of the 1,4addition product. This fact is in consistence with the theory on the interdependence between chemical properties of quinoneimines, particularly the regioselectivity of the addition to them, and their ORP.

Unexpected results have been obtained during investigation of the properties of some aminoderivatives of the quinine arenalazines (IVa, $\mathrm{b}, \mathrm{c})$. Despite the presence of the free positions in the quinoid cycle, these compounds did not react with hydrogen chloride (Scheme 9).

After prolonged boiling, the partial hydrolyze of quinoneimine was observed, but there was noformation of any new product. These compounds do not react with amines too. Probably, it is the first example when non-substituted quinoid cycle remains inactive in the reactions with both soft and hard nucleophiles. Possibly, such deactivation may be caused by a considerable decrease in the ORP as a

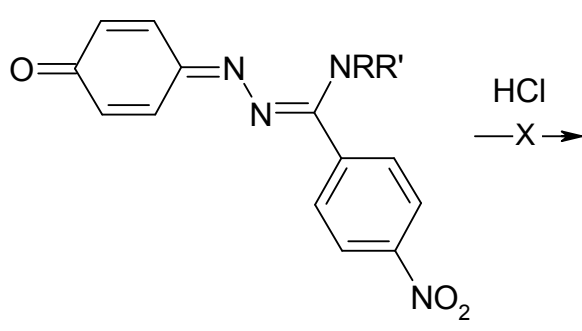

IV a: $\mathrm{R}=\mathrm{R}^{\prime}=\mathrm{C}_{2} \mathrm{H}_{5}-$

IV b: R = R' = i- $\mathrm{C}_{3} \mathrm{H}_{7}$

IV c: $\mathrm{R}=\mathrm{H}, \mathrm{R}^{\prime}=\mathrm{p}-\mathrm{CH}_{3} \mathrm{O}-\mathrm{C}_{6} \mathrm{H}_{4}$

Scheme 9

result of embedding aminogroup in the molecule. This fact is of great interest from the perspective of quinoid compounds metabolism in natural objects and needs to be explored additionally.

Thus, we have shown that the products of hydrogen chloride addition to the quinonearenalazines are quinogenic, and corresponding quinoid forms of these substances react with hydrogen chloride to form the mixture of the isomers. The ratio between these isomers depends on the ORP of initial quinoneimine. The products of the 1,8-addition of amines to quinonearenalazines do not react neither with hydrogen chloride nor with amines.

\section{Experimental}

Initial compounds (I), (II) and (IV) have been synthesized by the methods described elsewhere [9]. For the express control of the reaction fullness and qualitative analysis of the reaction mixture, thinlayer chromatography on Merck Kieselgel $60 \mathrm{~F}_{254}$ 
plates has been used with 1,2-dichloroetane or mixture of dichloroethane:propane-2-ole in proportion 9:1 as an eluent. Silica gel ROCC (80200 mesh fraction) has been usedfor column chromatography with chloroform as a solvent and dichloroetane as an eluent. PMR spectra have been recorded by the Jemini 2000 radiospectrometer (operating frequency of $400 \mathrm{MHz}$, internal standard is TMS, with DMSO- $\mathrm{d}_{6}, \mathrm{CDCl}_{3}$ or $\left(\mathrm{CH}_{3}\right)_{2} \mathrm{CO}-\mathrm{d}_{6}$ as solvents).

Synthesis of the $N$-( $\alpha$-chloro-benzylidene $)-N$ '(2(3)-chloro-4-hydroxyphenyl)hydrazines $(V)$

The portion of quinone imine (III) of about 4 mmol was solved in $100-120 \mathrm{~mL}$ of $1,2-$ dichloroethane at heating and $5 \mathrm{~mL}$ of $30 \%$ hydrochloric acid was added. The solution was intensively stirred for 1 hour, and then $200 \mathrm{~mL}$ of water was added. The reaction mixture was intensively shaken, the water layer was decanted, and this operation was repeated 3-4 times. The organic layer was separated and evaporated by using a rotary evaporator unto $10-15 \mathrm{~mL}$. This mixture was analyzed by TLC (for IIIa, b), or separated via column chromatography (in the case of IIIc), or subjected to oxidation by the method described below (in the case of IIId). To prepare compounds (Vc, c') in a pure form after column chromatography, the corresponding fractions were dried to dryness; the formed crystals were repeatedly washed with hexane and dried again. Yields: Vc-11\%, IVc'-53\%. Light yellowcrystals, melting points are $186-188^{\circ} \mathrm{C}$ and $179-181^{\circ} \mathrm{C}$ respectively.

Synthesis of the $N$-( $\alpha$-chloro-benzylidene)hydrazono-3(4)-chloro-2,5-cyclohexadiene-1-ones (VI)

The method was the same as described elsewhere [9] for the synthesis of quinonearenalazines, only chlorine derivatives (V) must be used as initial compounds. Yields: VIc - 72\%, VI c'- $68 \%$, VI d' $-42 \%$ (if using concentrated solution after rotary evaporator from previous method). Brown crystals, melting points are $168-170^{\circ} \mathrm{C}, 164-166^{\circ} \mathrm{C}$ and $144-$ $146^{\circ} \mathrm{C}$, respectively.

\section{REFERENCES}

1. Adams R., Reifschneider $W$. The synthesis and reactions of quinine mono- and di-imides // Bull. Chem. Soc. France. 1958. - No. 1. - P.23-64.

2. Бурмистров К.С., Юрченко А.Г. Присоединение хлористого водорода к $\mathrm{N}$-арил-1,4-бензохинонмоноиминам // Журн. орган. хим. - 1985. - Т.21. - № 3. - С.575-578.
3. Бурмистров К.С., Глух А.И., Торопин Н.В. Окислительная циклизация N-(п-толил)-2,5-ди(п-толиламино)-1,4бензохинонимина // Журн. орган. химии.- 2005. - № 6. С.959-960.

4. Взаимодействие $\mathrm{N}$-арилсульфонилпроизводных 1,4-бензохинонмоноимина с этиловым эфиром бензоилуксусной кислоты / С.А. Коновалова, А.П. Авдеенко, Е.Н. Лысенко, М.Д. Обушак // Вопр. химии и хим. технологии. 2017. - № 3 - C.14-18.

5. Transimination of quinone imines: a mechanism for embedding exogenous redox activity into the nucleosome / Ye W., Uthpala I., Seneviratne N., et al. // Chem. Res. Toxicol. - 2012. - Vol.25. - No. 12. - P.2627-2629.

6. Smith R.A., Murphy M.P. Animal and human studies with the mitochondria-targeted antioxidant MitoQ // Ann. N.Y. Acad. Sci. - 2010. - Vol.1201. - P.96-103.

7. Bolton J.L., Dunlap T. Formation and biological targets of quinones: cytotoxic versus cytoprotective effects // Chem. Res. Toxicol. - 2017. - Vol.30. - P.13-37.

8. Авдєєнко А.П., Коновалова С.О. Хіноніміни: від протиракових препаратів до молекулярних комп'ютерів: Монографія. - Краматорськ: ДДМА, 2018. - 516 с.

9. Реакция присоединения галогенводородов к аренальазинам 1,4-бензохинона / Б.В. Мурашевич, К.С. Бурмистров, Н.В. Торопин, С.А. Коновалова // Вопр. химии и хим. технологии. -2010 . - № 6. - С.23-27.

10. Мурашевич Б.В., Бурмистров К.С., Торопин Н.В. Реакции аренальазинов $\mathrm{N}$-аренсульфонил-1,4-бензохинондииминов с галогеноводородами // Вопр. химии и хим. технологии. - 2011. - № 3. - С.162-163.

11. Мурашевич Б.В., Бурмистров К.С., Торопин Н.В. Взаимодействие аренальазинов 1,4-бензохинона с вторичными алифатическими аминами // Вопр. химии и хим. технологии. - 2011. - № 1. - С.14-18.

12. Мурашевич Б.В., Шрейбер К.А., Лебедь О.С. Синтез 1-(4-гидроксифенил)-3-(4-нитрофенил)-5-алкил-1,2,4-триазолов // Известия высших учебных заведений. Химия и химическая технология. - 2015. - Т.58. - № 4. - C.7-9.

13. Murashevych B., Toropin N., Burmistrov K. Reaction of 4-[2-(arylmethylidene) hydrazinylidene] cyclohexa-2, 5-dienones with aromatic amines // Russ. J. Org. Chem. - 2013. - Vol.49. - No. 10. - P.1466-1469.

14. Бурмистров С.И., Бурмистров К.С., Малиновский М.С. Окислительно-восстановительные потенциалы систем хиноназин-диоксиазосоединение// Журн. орган. химии. 1976. - T.12. - № 10. - С.2193-2196.

15. Торопин Н.В., Бурмистров К.С. Присоединение хлористого водорода к N-(п-толил)-1,4-бензохинонмоноимину и его хлорзамещенным // Журн. орган. химии. - 1985. T.21. - № 7. - C.1544-1550.

Received 18.02.2019 


\section{ХІМІЧНІ ВЛАСТИВОСТІ ДЕЯКИХ НОВИХ ПОХІДНИХ XIHOHIMIHIB}

\section{Б. Мурашевич, Н. Ничик, М. Торопін, Я. Труш, К. Бурмістров}

Досліджені реакції деяких С8-заміщених аренальазинів хінонів, а саме їх хлор- та амінопохідних, з гідроген хлоридом. Показано, що у випадку хлорпохідних ці реакиії незалежно від розчинника, що застосовувався, приводять до утворення суміші ароматичних продуктів 1,4- та 6,3-приєднання. Співвідношення між иими ізомерами залежить від окисно-відновного потенціалу вихідного хіноніміну. Підвищення акцепторних властивостей замісника в ароматичному кільці молекули субстрату веде до зростання вмісту продукту 1,8-приєднання. Продукти приєднання є хіногенними та можуть бути окиснені до відповідних хіноїдних форм. Останні у випадку 6,3-приєднання хлороводню існують тільки у анти-формі, в той час як окиснені продукти 1,4-приєднання являють собою суміш син- та антиізомерів, про шо переконливо свідчать спектри ЯМР иих сполук. Амінопохідні аренальазинів хінонів не реагують ані з гідроген хлоридом, ані з амінами, вірогідно, через значне зниження електронодефіцитності під дією аміногрупи, що введена.

Ключові слова: хіноніміни, аренальазини хінонів, приєднання, регіоселективність, окисно-відновні потенціали, гідроген хлорид.

\section{CHEMICAL PROPERTIES OF SOME NEW QUINONEIMINE DERIVATIVES}

\section{B. Murashevych ${ }^{a, b, ~}{ }^{,}, N$. Nychyk $^{a}$, N. Toropin ${ }^{a}, Y$. Trush $^{a}$, K. Burmistrov a}

a Ukrainian State University Of Chemical Technology, Dnipro, Ukraine

b State Institution «Dnipropetrovsk Medical Academy of the Ministry of Health of Ukraine», Dnipro, Ukraine

* e-mail: murashevych.b@gmail.com

The reactions between some $C_{8}$-substituted quinone arenalazines (their chloro- and amino-derivatives) and hydrogen chloride were investigated. It is shown that in the case of chloroderivatives these reactions lead to the formation of the aromatic 1,4and 6,3-addition products mixture, regardless of the used solvent. The ratio between these isomers depends on the oxidation-reduction potential of initial quinoneimine. An increase in the acceptor properties of the substitute in the aromatic ring of substrate results in an increase in the content of 1,4-addition product. The addition products are quinogenic and can be oxidized to the corresponding quinoid forms. The last mentioned compounds exist only in anti-form in the case of 6,3-addition of hydrogen chloride, while oxidized 1,4-addition products are the mixture of syn- and anti-isomers, which convincingly follows from the NMR spectra of these compounds. Amino-derivatives of quinone arenalazines do not react neither with hydrogen chloride nor with amines, perhaps, due to a considerable decrease in electron deficiency of quinoid cycle under the influence of entered aminogroup.

Keywords: quinoneimine; quinone arenalazine; addition; regioselectivity; oxidation-reduction potential; hydrogen chloride.

\section{REFERENCES}

1. Adams R., Reifschneider W. The synthesis and reactions of quinine mono- and di-imides. Bulletin de la Societe Chimique de France, 1958, vol. 1, pp. 23-64.

2. Burmistrov K.S., Yurchenko A.G. Prisoedinenie khloristogo vodoroda $\mathrm{k}$ N-aril-1,4-benzohinonmonoiminam [Addition of hydrogen chloride to N-aryl-1,4benzoquinonemonoimines]. Zhurnal Organicheskoi Khimii, 1985, vol. 21, no. 3, pp. 575-578. (in Russian).
3. Burmistrov K.S., Glukh A.I., Toropin N.V. Oxidative cyclization of N-p-tolyl-2,5-bis(p-tolylamino)-1,4-benzoquinone imine. Russian Journal of Organic Chemistry, 2005, vol. 41, pp. 944-945.

4. Konovalova S.A., Avdeenko A.P., Lysenko E.N., Obushak M.D. Vzaimodeystvie N-arilsulfonilproizvodnykh 1,4benzokhinonmonoimina s etilovym efirom benzoiluksusnoi kisloty [Reaction of $\mathrm{N}$-arylsulfonyl derivatives of 1,4-benzoquinone monoimine with ethyl benzoylacetate]. Voprosy Khimii $i$ Khimicheskoi Tekhnologii, 2017, no. 3, pp. 14-18. (in Russian).

5. Ye W., Seneviratne U.I., Chao M.-W., Ravindra K.C., Wogan G.N., Tannenbaum S.R., Skipper P.L. Transimination of quinone imines: a mechanism for embedding exogenous redox activity into the nucleosome. Chemical Research in Toxicology, 2012, vol. 25, pp. 2627-2629.

6. Smith R.A.J., Murphy M.P. Animal and human studies with the mitochondria-targeted antioxidant MitoQ. Annals of the New York Academy of Sciences, 2010, vol. 1201, pp. 96-103.

7. Bolton J.L., Dunlap T. Formation and biological targets of quinones: cytotoxic versus cytoprotective effects. Chemical Research in Toxicology, 2017, vol. 30, pp. 13-37.

8. Avdeenko A.P., Konovalova S.O., Khinoniminy: vid protyrakovykh preparativ do molekulyarnykh komp'yuteriv [Quinoneimines: from anti-cancer drugs to molecular computers]. DDMA Publishers, Kramators'k, 2018. 487 p. (in Ukrainian).

9. Murashevich B.V., Burmistrov K.S., Toropin N.V., Konovalova S.A. Reaktsiya prisoedineniya galogenvodorodov $\mathrm{k}$ arenalazinam 1,4-benzohinona [Reaction of addition of hydrohalogenes to quinone arenalazines]. Voprosy Khimii $i$ Khimicheskoi Tekhnologii, 2010, no. 6, pp. 23-27. (in Russian).

10. Murashevich B.V., Burmistrov K.S., Toropin N.V. Reaktsii arenalazinov $\mathrm{N}$-arensulfonil-1,4-benzohinondiiminov s galogenovodorodami [Reactions between arenalazines of $\mathrm{N}$ arylsulphonyl-1,4-benzoquinonediimides and hydrohalogenes]. Voprosy Khimii i Khimicheskoi Tekhnologii, 2011, no. 3, pp. 162163. (in Russian)

11. Murashevich B., Toropin N., Burmistrov K. Vzaimodeistvie arenal'azinov 1,4-benzokhinona s vtorichnymi alifaticheskimi aminami [Interaction between quinone arenalazines and secondary aliphatic amines]. Voprosy Khimii i Khimicheskoi Tekhnologii, 2011, no. 1, pp. 14-18. (in Russian).

12. Murashevych B.V, Shrejber K.A., Lebed O.S. Sintez 1-(4-gidroksifenil)-3-(4-nitrofenil)-5-alkil-1,2,4-triazolov [Synthesis of 1-(4-hydroxyphenyl)-3-(4-nitrophenyl)-5-alkyl1,2,4-triazoles]. Izvestiya Vysshikh Uchebnykh Zavedenii. Khimiya i Khimicheskaya Tekhnologiya, 2015, vol. 58, no. 4, pp. 7-9. (in Russian).

13. Murashevich B.V., Burmistrov K.S., Toropin N.V. Reaction of 4-[2-(arylmethylidene) hydrazinylidene] cyclohexa2,5-dienones with aromatic amines. Russian Journal of Organic Chemistry, 2013, vol. 49, pp. 1466-1469.

14. Burmistrov S.I., Burmistrov K.S., Malinovskiy M.S. Okislitelno-vosstanovitelnye potentsialy sistem khinonazindioksiazosoedinenie [Oxidation-reduction potentials of the quinoneazine-dioxyazocompound systems]. Zhurnal Organicheskoi Khimii, 1976, vol. 12, no. 10, pp. 2193-2196. (in Russian).

15. Toropin N.V., Burmistrov K.S. Prisoedinenie khloristogo vodoroda $\mathrm{k} \mathrm{N}$-(p-tolil)-1,4-benzokhinonmonoiminu i ego khlorzameschennym [Addition of hydrogen chloride to $\mathrm{N}$ (p-tolyl)-1,4-benzoquinonemonoimine and its chlorine derivatives]. Zhurnal Organicheskoi Khimii, 1985, vol. 21, no. 7, pp. 1544-1550. (in Russian). 